\title{
Accidents of the Regional Education in the Sphere of Culture and Arts of the Contemporary Russia
}

\author{
Irina I. Irkhen* \\ Vaganova Ballet Academy \\ 2 Rossi Str., St. Petersburg, 191023, Russia
}

Received 08.02.2015, received in revised form 03.12.2015, accepted 05.01.2016

The subject of the present research is comprised by the regional processes in sphere of culture and arts through the prism of personality. On the material of the applied sociological study by the author in eight subjects of the Russian Federation we have singled out image-bearing accidents of regional education in the sphere of culture and arts, not connected with its essence, but springing up under an influence of globalization realia: e.g. subjective hedonization of education; career-and-position life strategy, parallel to ousting of the spiritual component into the background of the professional existence; domination of the ethnic factor as the basis of relations in poly-ethnic regions; strongly evident critical phenomena in the period of mastering a profession; low degree of accepting a profession as a form self-realization of personality; the loss of significance of the professional life activity. The research used the methods of analysis and synthesis, of grouping the data, factor analysis, field socio-cultural research. The scientific novelty of the research is associated with singling out of the development trends of regional education in the sphere of culture and arts in the conditions of the global "challenges", which increase possibilities of its multi-aspect optimization. The article has proved a provision about an expansion of practically oriented functional framework of education in the field of culture and arts, granting the creative youth a basis for the public, communicative activity. The general picture of the educational process in the field culture and arts forms a complicated vector reality having its own specific features in each region, which are determined by the economic status of the territory, its geographical position, uniqueness of the resident ethnoses, the extent of development of the educational system. The idea of a transformation of internal, spiritual senses of man towards the external consumer interests and a possibility of their restoration through the system of education and training the cadres is prospective for practical usage.

Keywords: culture, education, educational process in the field culture and arts, educational accents, Russian regions.

DOI: 10.17516/1997-1370-2016-9-2-481-490.

Research area: culture studies, pedagogy.

(C) Siberian Federal University. All rights reserved

* Corresponding author E-mail address: irkhen67@gmail.com 


\section{Introduction}

Contemporary reality with its swift transformations of the surrounding medium, of social institutions, human existence - initiates the appearance of new global threats, embracing all clusters of the system: "man - nature - society". According to the point of view of experts, the most destructive force emanates from those threats, which irradiate from the humanitarian vector of the civilization and affect its nucleus [Kolin, 2914; Remizov, 2004]. We mean here a crisis of the spiritual culture with its contradictory unity and interconnection with other spheres of social life. The basic manifestations of this crisis may be considered: lowering of the intellectual and cultural level of society; devaluation of commonly accepted values; the growth of a non-motivated aggression; a deformation of the cultural and historical memory; atomization of the Russian society, etc. [Astafyeva, 2005; Osnovy gosudarstvennoi kul'turnoi politiki, 2014].

The Year of Culture which has just ended, highlighted the vector of the spiritual renewal of the country - realization of culture as a value in itself, as the "symbol of the greatness of Russia" [Vladimir Putin, 2014], as one of the most important resources of the public development, the "field" of self-creation and enrichment of essential forces of man. More and more evident the idea of cultural stability becomes, which, determining the future of culture, science, education, religion, - simultaneously generates a creative economy, imbued with a culture-oriented beginning.

It is worth noting, that culture and education didn't exist autonomously historically [Irkhen, 2011b]. Aggravation of metamorphoses in one field unavoidably was projected onto another field. "Mirror reflection effect" accompanied successful overcoming of "crises" and a transfer to sustainable development. Such-like interconnection is predetermined by the very essence of these phenomena, their influence on the spiritual and moral progress. It is not by chance, that in the culturological discourse we observe the growth of interest in education, which more and more often is contingent on the fundament of "the clever economy" and the priorities in the country's development [Kolin, 2014], as well as on the factor of its national security [Kostin, Kostina, 2013], on the spiritual resource of civilization [Ikonnikova, 2005] and on the creation of the space of ideal senses [Abdulatipov, 2012]. Besides, "the secondary modernization" under way in the country, being determined by innovation in the knowledge and its translation, the quality of life, quality of economy [Lapin, 2012 , p. 5], as a matter of fact, postulates the necessity of consideration of education, including education in the sphere of culture and arts as a phenomenon of the contemporary cultural process, a mechanism of constant self-renewal of culture [Irkhen, 2011b, p. 103].

All this leads to the idea that, while drafting educational models, it is necessary to take into account congruence of education with the social development of the state in the cultural epoch, in the framework of which it came into being and is functioning. This thesis is actualized also with a diversity of Russian territories, their specific traits and attributions. The regions as "a socio-cultural entity" [Avanesova, Astafyeva, 2004], as a natural historical phenomenon have a considerable complex of economic, geo-natural and ethno-cultural constituents, capable of creating and materializing their own development priorities. All the above-said makes it possible to speak of self-values of the regional socio-cultural processes outside their balance with the state system, as well as about the unavoidable pulsation of common vectors [Irkhen, 2011a].

However, the influence of objective and subjective factors on functioning of the educational system, vary from region to region. On the one 
hand, specifics of life activities of the people on the given territory make themselves felt, on the other hand we should note different axiological attitude to the institute of education. Objective factors are those given by the state: socioeconomic, politico-regional, ethnic and spiritual. Subjective factors are a product of educational norms and processes mediated by the regional life experience and by individual psychological peculiarities of the students [Irkhen, 2014].

\section{Methods of research}

With the purpose of a study of educational processes through the prism of specific features of man we have carried an applied sociological research in eight subjects of the Russian Federation (Moscow, regions of Belgorod, Bryansk, Chelyabinsk, Kostroma, Smolensk, Tambov and the Perm' Territory), The representativeness of information was provided by the "nest" sampling - 937 students from 12 educational establishments, who studied in the directions and specialities of training according to the Federal state educational standards of the group "Arts and Culture". The materials were processed applying the methods of grouping the data and factor analysis with the aim of singling out of the causesequence ties of the development of education in the field of culture and arts in the concrete sociocultural realia and for an improvement of cadres training.

\section{The basic accidents}

The conducted analysis allows for delineating of the following figurative meaningful accidents of the regional education in the field of culture and arts, not connected with its essence, but arising under the influence of globalization realia: subjective hedonization of education; career-and-position life strategy alongside with ousting the spiritual constituent to the background from the professional existence; domination of the ethnic factor as the basis of inter-relations in poly-ethnic regions; strongly pronounced critical phenomena in the period of mastering a profession; a low degree of acceptance of a profession as a form of selfrealization of personality; the loss of senses of professional life activity, etc.

The key indicator of the Russian regions has become the question of ranking in the decreasing order of the significance of the offered factors, influencing the creation of the personality of a specialist in the field of culture. Groups of students have been singled out: those interested in the culture of the region, those disinterested and those who found it difficult to answer the question. At this we relied on the specifics of the cultural process, when "a person known to them is already incapable to hide himself behind those subjects, which could make happy a person who has much lower level of such interests" [Kitov, 2001, p. 81].

For the citizens of Smolensk disinterested in culture, the determining factors became socioeconomic ones, as region-creating, though equal to politico-regional factors, revealing the state of the regional economy. These data are in good conformity with the materials of the research conducted by The Institute of Philosophy of the Russian Academy of Sciences [Lapin, 2012, p. 19]. The noticeable low production rate in the sphere of services, low payment rate, condition a transfer of the region to the informational society ("the secondary modernization") in the range, lower than the average all-Russia trend. A disbalance of the social functions of this particular region of the Russian Federation tells on the index of social feelings of the population. Hence there is a quite explicable gap between the growing demands of the region's residents and low possibilities of the development of "the human potential". The situation is aggravated by the fact that the factor of stimulating a professional growth, has undergone 
an influence of the western mentality, created mostly on pragmatism, The students associate their professional growth with career-position strategy borrowed from abroad, despite the fact that the system of stimulation of professional growth is to encourage a further personality selfactivation. An important part here belongs to the ethnic determinants.

Equalizing the factor of enhancing of the professional growth with the ethno-cultural factor is in full accordance with the traditions, way and style of life of the Russian man. In the Smolensk region there live representatives of about 100 ethnoses (with a prevalence of the Russians), but only 26 national-cultural autonomies have been registered. In this connection, it is necessary to take into account the unity of universal human values with the creative development of personality. Striving for the professional selfrealization, the specialist of culture doesn't enrich only his own spirituality, but also aims other people at the spiritual communication with masterpieces.

Characteristically, in regions of the Central Federal Okrug with low indicators of "the secondary modernization" (the Bryansk and Kostroma regions) [Lapin, 2012, p.17] the first rating positions in the students' conscience are practically the same: ethnic factors, the crisis of professional growth, political and regional factors. Here we find a confirmation of sociologists' thesis about the probability: the ethno-national factor may overshadow social, economic and spiritual problems, which "will exhibit themselves in the national coloring, in "the ethnic wrapping" [Toshchenko, 2002, p. 101]. In the central regions the Russians amount to 96 p.c, but, however, ethnoses compile "specific inner differentiation of human species" (L.N. Gumilyov) forming their own cultural loci. This encourages education in the sphere of culture and arts to concentrate on ethno-cultural direction [Irkhen, 2011a].
The significance of ethnic factors is expressly reflected in the Urals regions (the first rating place), where the mountain-extractive type of culture has taken shape with its own world outlook, behavior ethics, the forms of spiritual-practical life activity. Through these factors the students see their belonging to the "small" and "large" motherland, the basis of mutual understanding of all people living on this territory. With all the inner heterogeneity of the population - for instance, there are more than 120 ethnoses of the Perm' Territory - the region remains a muster of a high level of confessional tolerance, a low level of tensions and conflicts on the religious ground. To a great extent this is due to the usage in official spheres alongside with Russian of the Komi-Permyak language, and also functioning of educational establishments with the study in Tatar language, with the simultaneous preservation of the Russian culture as the basis of the spiritual unity of the nations.

Primary significance of political-regional factors in the group of Muscovites, not interested in culture is caused by their subconscious "involvement" into the process of globalization. According to the data of foreign research, Moscow is the only Russian city, recognized as a global city of the world due to its high cultural level [Issledovanie A.T. Kearney, 2014]. In the mean time as outstanding Russian philosopher and sociologist N.I. Lapin marks, the capital metropolis, having formed "the binary nucleus", within the past ten years has reached in the dynamics of the "secondary modernization" the level of Sweden, relative to the world rank [Lapin, 2012, p.14]. In the orbit of the same growth rate there is also the Moscow region, which has risen from the average Russian level to the world one. Existence in the conditions of potential marginalism creates "scissors" between artistic preferences and inner spiritual-moral practice. This gap may be corrected by the educational 
system with its orientation onto social-spiritual constituent.

\section{Spiritual orientations and professional realization}

Placement of motives and senses of professional activity onto the very last places in six regions simultaneously (the Bryansk, Belgorod, Kostroma, Chelyabinsk, Smolensk regions and Moscow) practically reveals the axiological attitude to the profession. It is obvious, if the professional self-realization is valuable and accessible in its significance to a person, then his aspirations will be aimed at successful, intense studies. However, in this case we observe the reverse: the group disinterested in culture doesn't see any sense in the future profession as well.

In the group of those students who are interested in culture, the first place in all the regions is occupied by a crisis in the period of mastering the profession, i.e. a certain disbalance in the assessment of the professional choice, caused by sharp changes in the vector of the professional development of personality. This crisis is initiated by dissatisfaction with the professional training, disillusionment in the profession being got, dissatisfaction with some subjects studied, doubt as to the correctness of the choice made, and reformation of the leading kind of activities. "Being" whipped by globalization and the market of educational services, with such people the imperative character of the educational tradition is changed for "consumer preferences". A sharp interest in the professional actions in educational establishments outside their social, spiritual context forms "a double eccentric" of its own kind. The inner state of personality is summed up with the professional content, but the educational system demonstrates "the moment of failure". Smoothing it over is effected by the enculturation, as the basis of the further working out of the world outlook, political, social, religious and artistic preferences. The critical manifestations are also minimized by way of the students' involvement into culture-creating activities. Otherwise, there appears dissatisfaction with the profession, what has been proved by the placement of the motives and senses of the professional activities by the group of interested students of five regions (Belgorod, Smolensk and Tambov regions, the Perm' Territory and the city of Moscow) onto the last position. In certain regions (the Bryansk and Kostroma regions, the Perm' Territory) an analogous tendency is felt with respect to socio-professional activities of a specialist in the market-oriented conditions.

The analysis of the initial satisfaction or dissatisfaction with the profession among students reveals certain incongruence, a specific bifurcation moment in the group of interested respondents. Thus, only 55.1 p.c. of the Perm' students, interested in culture were satisfied with their professional growth; the rest, i.e., 44.9 p.c. answered "no" or "don't know". This is the highest indicator in the regions under study. In Moscow such students are three tines fewer - 13.3 p.c. Low quality of education marked by the students, expressed among other drawbacks the following features - a formality of communication between the teacher and the student; a little proportion of the practical experience; multi-subject part of the curriculum not connected with the profession; absence of professional upgrading - all this finally results in drop-out of the youth from the branch of culture.

Ranking spiritual factors as last in the list, by the interested students of Smolensk and Moscow reproduces the influence of globalization spirituality is comprehended as the leadership of idealized and material benefits. In the Smolensk region the influence of the metropolitan agglomeration is strongly felt.

The group of those who had difficulties with expressing themselves about their interest in 
the culture of their region, reveal the priority of the factor of life-important events (the Tambov region), shifting the subsequent positions of the semantic field: a crisis of the professional growth, ethnic factors, political-regional factors. With the students experiencing difficulties in answering the questionnaire some placed spiritual factors onto the last but one place (those in Bryansk, Tambov and Moscow), and some (Kostroma) onto the very last. Hence we draw a conclusion that education in the field of culture and arts, in accordance with its culturological essence, is destined to bring up a "spiritual instinct", to form the lost senses of life, since "the integrity of personality is determined by the degree of generalization and stability of spirituality around o certain system of cultural values, norms, and reference-points" [Remizov, Irkhen, 2014, p. 142].

\section{Market accidents}

The materials of this research and literature data testify that education in the sphere of culture and arts undergo segment changes in the framework of market-oriented economy. Region-making specifics form a definite factor field, yielding a multi-dimensional notion of education in the sphere of culture and education as comprehended by the students.

An important and increasingly striking trend appears to be the broadening of the functional framework of education in the sphere of culture and arts, providing the creative youth with the basis for professional communicative activities. The regional cultural medium is a considerable prerequisite for personal success and well-being of the residents. Practically, the territorial development of the region, rising labour productivity, social mobility of the citizens are determined by the well-balanced, synchronous character of the cultural mediun, and its correlation with the economy of the region.
Taking into account the fact that the outer field of the regional educational processes has such inherent features as dynamism and stagnation, a changeable shift to this or that side, it may be assessed either positively, or negatively. Here very demonstrative are the data of this research, associated with opportunities opened up for the professional formation of the specialist by the socio-cultural medium. In each of the regions under study its own combinations of answers prevailed. For instance, in the Belgorod region the maximum choices (14.0 p.c.) were the following answers: "the socio-cultural medium stimulates self-development, enhances competitiveness at the labour market", "encourages acquisition of new knowledge, without limits of the narrow profile". In the Tambov region 22.5 p.c. of choices fell onto the answer "premonition of redundancy in the perspective of the chosen speciality". It is obvious, that here tells an extreme sluggishness and comlexity of the system of reproduction of artistic culture and arts, which remains in accordance of the tempo-rythmic of the past centuries [Sinetsky, Sinetskaya, 2014, p. 43]. However, such-like choice of the answer in other regions was minimal: the Bryansk region - 2.7 p.c., Moscow -6.7 p.c., the Kostroma region -6.9 p.c., the Chelyabinsk region -6.0 p.c., the Perm' territory - 9.1 p.c., in the Belgorod and Smolensk regions - not a single answer of the kind.

In the mean time in five regions simultaneously (the city of Moscow, the Kostroma, Smolensk, Chelyabinsk regions and the Perm' Territory) an opinion dominates, that sociocultural medium encourages an extension of the educational level. These students (up to 20 p.c.), successfully "manoeuvreing" in the framework of their profession, are mastering another profile of culture and arts.

It is evident that macro-social changes and new competition risks in the conditions of globalization give rise to different parameters 
of the professional behavior in the sphere of culture. Enforcing mastering of the new knowledge and skills, the socio-cultural milieu of the region at the same time gives a chance for additional earnings. This combination of answers, though non-dominant, still has spread over regions. Most probably, here market laws "are at work" and the market demands individual coaching of school-children, home classes with a music teacher, organization of children's holidays and "corporation" evening parties. An areal of mass culture is also expanding, in the form of entertainment "industry" and restaurant business, what improves financial opportunities of choreographers, variety singers, wind-percussion instruments performers. It is also worth noting diversification processes of specification of cultural areals, initiating the development of subsidiary professional education in the field culture and arts while getting higherschool education. This will provide the graduates with an opportunity to get more flexibly adapted to the labour market demands, "to find oneself" in adjacent branches: in mass media and information services, youth politics, showbusiness, advertising agencies and others. This phenomenon in a greater extent corresponds to the globalization trend, in conformity with which the employment of the population is shifting into the social sphere.

It seems that the attractiveness of a region on the whole, and a branch of culture in particular, is associated by young specialists with their further life plans. In economically successful and independent subjects of the Russian Federation, characterized by a high "index of human potential development" (according to the UN Program of Development data) the young people strive for construing their life strategies in the regional context. This is characteristic of Muscovites (the first place in the region by the Index of the Development of Human Potential -
IDHP for the year of 2013), of the citizens of the Belgorod region ( $5^{\text {th }}$ place) of the Chelyabinsk region $\left(20^{\text {th }}\right.$ place $)$ and the Perm' Teritory $\left(26^{\text {th }}\right.$ place) [Bobylev, 2013, p. 150-151]. Thus, the Perm' Territory being an independent "donorregion", with a diversified structure of the economy and a relatively high well-being, causes quite optimistic feelings of the population. It is not by chance, that the majority of graduates of a culture school of higher learning, find employment in the Perm' region according to the received qualification ( 80 p.c. of graduates). It is obvious, that culture contributes to the stability of life on that territory. In depressive regions, such as the Smolensk region $\left(57^{\text {th }}\right.$ place by IDHP in 2013), those employed in accordance are fewer (39.6 p.c.). Search for a highly-paid employment in the Moscow agglomeration leads to "the washing out" of the most mobile and highly qualified cadres.

Our research in eight subjects of the Russian Federation confirms the fact, that on the whole every third graduate of the educational establishment of culture is oriented onto a migration life strategy. In the conditions of growing globalization this turns into the inner migration of young cadres into megapolises.

In this way, the general picture of educational processes of the sphere of culture and art form a complex reality, the vectors of which sometimes mutually confront or supplement each other. In each region such reality has its own specific features, determined by the economic status of the territory, its geographical position, the uniqueness of the ethnoses resident on it, the level of development of the educational system.

\section{Conclusion}

Deep transformations in politics, economy and the spiritual sphere have become a global "challenge" for the societies of regional 
subjection. The dichotomy of "inner" and "outer" influences lays bare a multi-level character of the regional cultural processes, which show through all these as "a localization of globalization". Here we mean the rising role of regions as bearers of local-territorial senses in the architectonics of the united cultural space of the country.

Education in the sphere of culture and arts as a part of the contemporary cultural process also changes its "image" in the search of "an answer" to the "challenges" (A. Toynbee) of cotemporaneity. It is increasingly evident that modern collisions redistribution of economic and cultural capital, its concentration in economically developed regions, etc. - are reflected in education as if in the mirror. Being a connecting link between various elements of the cultural hierarchy of the regional socium, education in the sphere of culture and arts manifests itself as an adequate form of human universality development.

The conducted analysis of the regional educational processes in the sphere of culture and arts through the prism of sociometry reveals the connection of cultural changes with the social life of the territories, with the modernization under way. Taking into account the all-Russia trend towards an approximation of the cultures of regions we can see in them a "fan" of unique and multifarious phenomena with all their configurations.

The resulting reflection over education in the sphere of culture and arts highlights, on the one hand, its turning into a mechanism of culture genesis, of transformations of the existing models, generation of new cultural forms, and, on the other hand, the synchronous influence on the development of cultural process through personality. "Submergence" of an individual into a powerful stream of culture, occurring in the educational process, gives us a feeling of deep ties with the nation, its past, present and future. Such-like integrity contributes to timely overcoming of critical phenomena in the Russian society, filling its life with spiritual meanings and multiple increase of cultural presence in the globalizing world.

\section{References}

Abdulatipov, R.G. (2012) Chelovek i kul'tura: filosofiia i praktika dukhovnykh idealov [Person and Culture: Philosophy and Practice of Spiritual Ideals]. Moscow: 192 p. (In Russ.)

Avanesova, G.A., Astafyeva, O.N. (2004) Sociokul'turnoe razvitie rossiiskikh regionov: mehanizmy samoorganizatsii i regional'naia politika [Socio-Cultural Development of the Russian Regions: Mechanisms of Self-Organization and Regional Policy]. Moscow: 418 p. (In Russ.)

Astafyeva, O.N., Boykov, V.E., \& Egorov, V.K., Mezhuev, V.M., Toshchenko, Zh.T. (2005) Dukhovnaia kul'tura sovremennogo rossiiskogo obshchestva: sostoianie i tendentsii formirovaniia (materialy "kruglogo stola") [Spiritual Culture of Contemporary Russian Society: State and Tendencies of Formation (materials of a "panel talk")]. Sostiologiia vlasti, 3. P. 47-74. (In Russ.)

Bobylev, S.N., ed. (2013) Ustoichivoe razvitie: vyzovy Rio: doklad o chelovecheskom razvitii v Rossiiskoi Federatsii za 2013 god. [Sustainable Development: Challenges of Rio: a Report on Human Development in the Russian Federation for 2013]. Moscow: 202 p. (In Russ.)

Ikonnikova, S.N. (2005) Istoriia kul'turologicheskikh teorii [History of Culturological Theories]. Moscow: 473 pp. (In Russ.)

Irkhen, I.I. (2011a) Kul'turologicheskii analiz regional'nykh protsessov v sovremennoi Rossii [Culturological Analysis of Regional Processes in Contemporary Russia]. Filologiia i kul'tura, 23. P. 103-108. (In Russ.) 
Irkhen, I.I. (2011b) Obrazovanie v oblasti kul'tury i iskusstv kak fenomen sovremennogo kul'turnogo protsessa [Education in the Field of Culture and Art as a Phenomenon of Contemporary Cultural Process]. Nauchnoe obozrenie. Seriia 2: Gumanitarnye nauki, 5. P. 102-108. (In Russ.)

Irkhen, I.I. (2014) Vektornyi analiz obrazovatel'nogo protsessa $v$ sfere kul'tury i iskusstva $\mathrm{v}$ regionakh Rossii [Vector Analysis of the Educational Process in the Sphere of Culture and Art in the Regions of Russia]. Evropeiskii zhurnal social'nykh nauk, 3-2. P. 70-76. (In Russ.)

Issledovanie A.T. Kearney: indeks globalizatsii gorodov mira 2014 goda [Research A.T. Kearney: Index of Globalization of the Cities of the World of 2014] Available at: http:/gtmarket.ru/ news/2014/04/22/6737 (accessed 2 September 2014). (In Russ.)

Kitov, Iu.V. (2001) Chelovek interesujushchiisia [Homo interested]. Moscow; 255 pp. (In Russ.)

Kolin, K.K. (2014) Global'nye ugrozy razvitiia tsivilizatsii v XXI veke [Global threats to development of a civilization in the XXI century]. In: Strategicheskie prioritety. Vol.1. P. 6-30. (In Russ.)

Kostin, V.I., Kostina, A.V.(2013) Natsional'naia bezopasnost'sovremennoi Rossii: ekonomicheskie i sotsiokul'turnye aspekty [National security of modern Russia: economic and socio-cultural aspects]. Moscow: 344 pp. (In Russ.)

Lapin, N.I. (2012) Izmerenie modernizatsii rossiiskikh regionov i sotsiokul'turnye faktory ee strategii [Measurement of modernization of the Russian regions and sociocultural factors of its strategy]. Sotsiologicheskie issledovaniia, 9. P. 4-23. (In Russ.)

Osnovy gosudarstvennoi kul'turnoi politiki: utverzhdeny Ukazom Prezidenta Rossiiskoi Federatsii ot 24 dekabria 2014 goda №808 [The Foundations of the State Cultural Policy: are approved as the Decree of the President of the Russian Federation of December 24, 2014, № 808]. (In Russ.)

Remizov, V.A. (2004) Sotsial'naia ekologiia kul'tury lichnosti [Social Ecology of Culture of the Personality]. Moscow, 164 pp. (In Russ.)

Remizov, V.A., Irkhen, I.I. (2014) Culture of Personality in the Discourse of the Resource of Social Development. Nauka i chelovechestvo, 4-1. P. 138-146. (In English)

Sinetsky, S.B., Sinetskaya, T.M. (2014) Iskusstvo i intellektualizatsiya obshchestva: novyi staryi smysl kul turnoy politiki [Art and intellectualizaton of a society: the new old sense of cultural policy]. Vestnik Chelyabinskoi gosudarstvennoi akademii kultury i iskusstv, 3 (39). P. 41-45. (In Russ.)

Toshchenko, Zh.T. (2002) Politicheskaia sotsiologiia [Political sociology]. Moscow, 494 p. (In Russ.)

Vladimir Putin: «Nado ob"ediniat' intellektual'nye resursy i nauchnuiu infrastrukturu»: vystuplenie na zasedanii Soveta po nauke i obrazovaniiu ["It is necessary to unite intellectual resources and scientific infrastructure": speech at the meeting of Council for science and education] Available at: http://ruskline.ru/news_rl/2014/12/09 (accessed 10 December 2014). (In Russ.) 


\section{Акциденты регионального образования в сфере культуры и искусства современной России}

И.И. Ирхен

Академия Русского балета имени А.Я. Вагановой Россия, 191023, Санкт-Петербург, ул. Зодчего Росси, 2

Предмет исследования - региональные образовательные прочессы сферы культуры и искусства сквозь призму личности. На материале авторского прикладного социологического исследования в восьми субъектах Федерачии выделены значимые образные акииденты регионального образования в сфере культуры и искусства, не связанные с его сущностью, но возникшие под воздействием глобализационных реалий: субъективная гедонизация образования; карьерно-должностная жизненная стратегия с вытеснением духовной составляющей на второй план из профессионального бытия; доминирование этнического фактора как основы взаимоотномений в полиэтнических регионах; ярко выраженные кризисные явления в период освоения профессии; невысокая степень принятия профессии как формы самореализации личности; утрата смыслов профессиональной жизнедеятельности. В исследовании применялись методы анализа и синтеза, группировки данных, факторного анализа, полевые социокультурные исследования. Научная новизна исследования связана с выявлением трендов развития регионального образования в сфере культуры и искусства в условиях глобальных «вызовов», которые увеличивают возможности его многоаспектной оптимизачии. Доказано положение о растирении практико-ориентированных функииональных рамок образования в сфере культуры и искусства, обеспечивающего творческой молодежи базу для общественной, коммуникативной деятельности. Общая картина образовательного процесса сферы культуры и искусства образует сложную векторную реальность, которая в каждом регионе имеет свою спецификацию, детерминированную экономическим статусом территории, ее расположением, самобытностью проживающих этносов, развитостью образовательной системы. Идея о трансформачии внутренних, духовных смыслов человека в сторону внешних, потребительских интересов и возможности их восстановления через систему образования и подготовку кадров перспективна для использования в практике.

Ключевые слова: культура, образование, образовательный прочесс в сфере культуры и искусства, образовательные акиенты, российские регионы.

Научная специальность: 24.00.00 - культурология, 13.00.00-педагогические науки. 